\title{
ARRIVAL AND CLUTCH INITIATION OF DOUBLE-CRESTED CORMORANTS AT LAKE NEWELL, ALBERTA
}

by Kees Vermeer, Canadian Wildlife Service, Edmonton

A colony of Double-crested Cormorants (Phalacrocorax auritus) with 148 nests was found on a three-acre island in Lake Newell $\left(50^{\circ} 24^{\prime} \mathrm{N} ; 111^{\circ} 58^{\prime} \mathrm{W}\right)$, Alberta in 1967 (Vermeer, 1969. Can. Field Naturalist 83(1):36-39). The island was revisited during the springs of 1968 and 1969 to obtain information on the arrival and clutch initiation of the cormorants.

Figure 1 shows mean daily air temperatures for April 1968 and 1969 at the Brooks weather station, approximately 12 miles $\mathrm{NE}$ of the cormorant colony. It can be seen that the air temperatures were generally considerably higher for the first three and a half weeks in April 1969 than for the same period in 1968. Nevertheless, Lake Newell became ice-free during the first two or three days in April
1968 while in 1969 ice did not disappear from the lake until the end of the third week of that month. The earlier disappearance of ice in 1968 was probably caused by the higher temperatures during the winter months preceding.

In 1968, the cormorants occupied the nesting island two weeks after the lake ice disappeared, while in 1969 the birds occupied the island several days before its disappearance. On April 17, 1969, I also observed cormorants occupying a nesting island in Cypress Lake $\left(49^{\circ} 28^{\prime} \mathrm{N} ; 109^{\circ} 28^{\prime} \mathrm{W}\right)$, Saskatchewan, while the ice was still present. However, both lakes were open along their peripheries when the cormorants arrived in 1969 and fish was probably available to them.

Table 1 shows that the cormorants

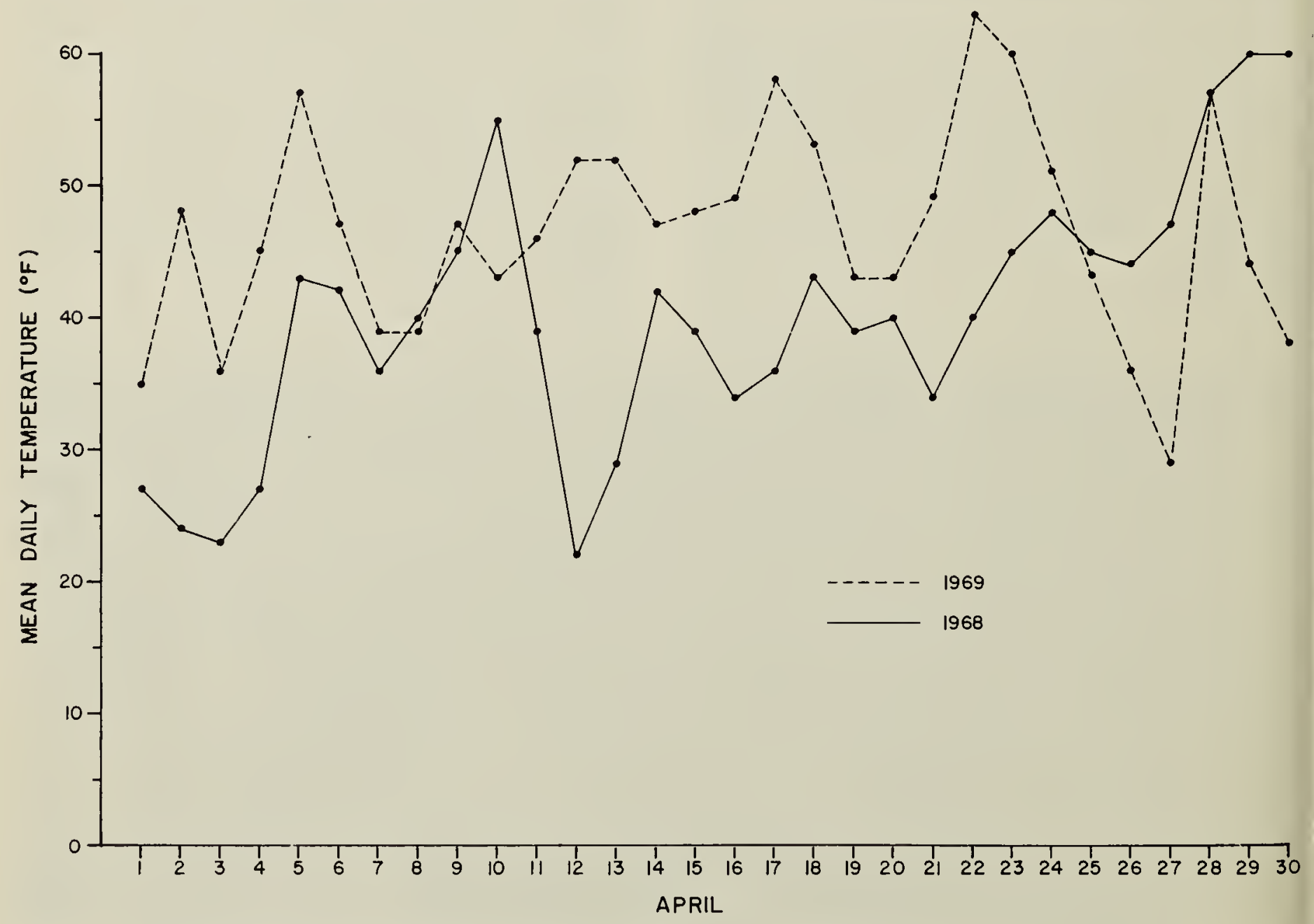

Fig. 1. Mean daily air temperature at Brooks, Alberta in April 1968 and 1969. 
Table 1. Arrival and clutch initiation of Double-crested Cormorants on their nesting island in Lake Newell in April 1968 and 1969.

\begin{tabular}{l|cc|cc|cr}
\hline & \multicolumn{2}{|c|}{$\begin{array}{c}\text { Number of cormorants } \\
\text { observed }\end{array}$} & \multicolumn{2}{|c|}{$\begin{array}{c}\text { Number of clutches } \\
\text { observed }\end{array}$} & \multicolumn{2}{|c}{ Mean clutch size } \\
& 1968 & 1969 & 1968 & 1969 & 1968 & 1969 \\
\hline April 16-17 & 11 & 80 & $\ldots$ & $\ldots$ & $\ldots$ & $\ldots . .17$ \\
April 23 & 104 & 240 & 0 & 18 & $\ldots$ & 1.17 \\
April 29-30 & $\ldots$ & $\ldots$ & 5 & 69 & 1.00 & 2.29 \\
\hline
\end{tabular}

at Lake Newell arrived in numbers and started to lay earlier in 1969 than in 1968. From the comparison of data in Figure 1 and Table 1 it appears that the earlier clutch initiation in 1969 may be related to the earlier arrival of cormorants and/or the pre- ceding higher air temperatures in April that year than in 1968.

Once clutch initiation had started in 1969 a temperature drop occurring in the last week of April (Figure 1) did not appear to inhibit egg-laying to much extent (Table 1).

\title{
PARASITES FROM COMMON GOLDENEYE, GREATER SCAUP AND OLDSQUAW COLLECTED ON BOUNDARY BAY, B.C., FEBRUARY, 1970
}

\author{
by Keith Hodson and Mary Grimble, Department of Zoology,
} U.B.C., Vancouver

During the winter of 1968-69 (Nov.Feb.) approximately two dozen diving ducks were found in a weak and emaciated condition along Boundary Bay near Beach Grove, B.C. A postmortem examination of many of these ducks which subsequently died showed that they were not the victim of gunshot wounds as had been suspected. It was then decided to examine some of these ducks more closely to determine what parasites they were carrying. Two specimens each of Common Goldeneye and Oldsquaw and one Greater Scaup were examined and all parasites were preserved. Other ducks found in a similar condition during that time included Surf Scoters, Canvasbacks, Ruddy Ducks and Buffleheads.

Table 1 summarizes the identification as far as possible, the abundance, and the location of parasites found in each duck.

Because no healthy ducks were collected it is not known what levels of parasite infestations a healthy duck normally carries. It is therefore diffcult to say whether or not the overabundance of parasites was a cause of decreased health in those ducks found; however, it appeared that these ducks were carrying very heavy infestations and this probably contributed in part to the cause of their death.

Since Boundary Bay is an area of very shallow water it is an important winter feeding area for many types of waterfowl, especially divers. This, combined with the abundance of small marine life which would provide intermediate hosts for most of these parasites, would seem to provide ideal conditions for the transmission of parasites between hosts. It is suggested that ducks arriving in an area such as this during migration would be in a somewhat lowered physical condition and therefore more subject to parasitic invasions.

Many of the ducks found in emaciated conditions were kept alive as long as possible in hopes that they 